\title{
A Calorimetric Study of Copper(II) Chloride Complexes in
}

\section{Aqueous Solution}

\author{
ROBERT ARNEK, ${ }^{a}$ IGNASI PUIGDOMENECH ${ }^{a}$ and MANUEL VALIENTE ${ }^{b}$
}

${ }^{a}$ The Royal Institute of Technology, Department of Inorganic Chemistry, S-100 44 Stockholm, Sweden and

${ }^{b}$ Universitat Autónoma, Departamento Quimica Analitica, Bellaterra-Barcelona, Spain

The complex formation between copper(II) and chloride ion in $5 \mathrm{M} \mathrm{Na}\left(\mathrm{ClO}_{4}, \mathrm{Cl}\right)$ medium at $25^{\circ} \mathrm{C}$ has been investigated with a flow microcalorimetric technique. By using equilibrium constants determined earlier, the enthalpy changes for the formation of the species $\mathrm{CuCl}^{+}, \mathrm{CuCl}_{2}$ and $\mathrm{CuCl}_{3}^{-}$ were obtained.

The weak complex formation between copper(II) and chloride ion in aqueous solution has been investigated mainly by spectrophotometric methods. ${ }^{1-17}$ Other methods which have been used are ion-exchange, ${ }^{22}$ ion exchange paper chromatography, ${ }^{23}$ kinetics, ${ }^{2}$ solvent extraction ${ }^{25}$ and calorimetry. ${ }^{10,16,18-21}$ Some of the results, obtained under conditions similar to those in the present investigation, are given in Table 1 . The $\beta_{n}$ and $\Delta \mathrm{H}_{\mathrm{n}}$ values refer to the reactions $\mathrm{Cu}^{2+}+n \mathrm{Cl}^{-} \rightleftarrows$ $\mathrm{CuCl}_{n}{ }^{(2-n)}$ with $n=1-4$. The existence of these complexes was first established by Bjerrum ${ }^{1}$ already in 1946 and has been confirmed by later investigators. $^{8}$

The main objective of the present work has been to determine reliable $\Delta \mathrm{H}$-values for the formation

Table 1. Some literature data for the system $\mathrm{Cu}(\mathrm{II})$ chloride at $25^{\circ} \mathrm{C}$.

\begin{tabular}{|c|c|c|c|c|c|c|c|}
\hline Ref. & Method & Medium & $\begin{array}{l}\beta_{1} \\
\mathbf{M}^{-1}\end{array}$ & $\begin{array}{l}\beta_{2} \\
\mathbf{M}^{-2}\end{array}$ & $\begin{array}{l}\beta_{3} \\
\mathbf{M}^{-3}\end{array}$ & $\begin{array}{l}\beta_{4} \\
\mathbf{M}^{-4}\end{array}$ & $\begin{array}{l}\Delta H_{1} \\
\mathrm{~kJ} \mathrm{~mol}^{-1}\end{array}$ \\
\hline 2 & spectr. & $1 \mathrm{M} \mathrm{HClO}_{4}$ & $1.30 \pm 0.03$ & $0.23 \pm 0.15$ & - & - & - \\
\hline $\begin{array}{r}5, \\
18\end{array}$ & $\begin{array}{l}\text { spectr. } \\
\text { calorim. }\end{array}$ & $2 \mathrm{M} \mathrm{NaClO}_{4}$ & $1.22^{-}$ & - & - & - & 6.6 \\
\hline 23 & $\begin{array}{l}\text { paper } \\
\text { chromat. }\end{array}$ & $3 \mathrm{M} \mathrm{HClO}_{4}$ & $0.94 \pm 0.05$ & $0.16 \pm 0.07$ & $0.05 \pm 0.08$ & - & - \\
\hline 19 & calorim. & $2 \mathrm{M} \mathrm{NaClO}_{4}$ & $0.96 \pm 0.01$ & - & - & - & $8.2 \pm 0.2$ \\
\hline 24 & kinetics & $1 \mathrm{M} \mathrm{NaClO}_{4}$ & $1.30 \pm 0.27$ & - & - & - & - \\
\hline 10 & $\begin{array}{l}\text { spectr. } \\
\text { calorim. }\end{array}$ & $3 \mathrm{M} \mathrm{NaClO}_{4}$ & $0.87 \pm 0.08$ & - & - & - & $9.3 \pm 0.2$ \\
\hline 21 & calorim. & $3 \mathrm{M} \mathrm{LiClO}_{4}$ & 0.83 & - & - & - & 12.1 \\
\hline 11 & spectr. & $4 \mathrm{M} \mathrm{NaClO}_{4}$ & $1.52 \pm 0.02$ & - & - & - & - \\
\hline & & $5 \mathrm{M} \mathrm{NaClO}_{4}$ & $1.86 \pm 0.04$ & $\overline{7}+06$ & $\overline{1} 06+025$ & - & - \\
\hline $\begin{array}{l}12 \\
14\end{array}$ & spectr. & $\mathrm{M} \mathrm{MaClO}_{4}$ & $\begin{array}{l}4.0 \pm 0.7 \\
1.3+0.1\end{array}$ & $\begin{array}{l}4.7 \pm 0.6 \\
-\end{array}$ & $1.96 \pm 0.25$ & $\begin{array}{l}0.23 \pm 0.05 \\
-\end{array}$ & - \\
\hline & spectr. & $6 \mathrm{M} \mathrm{NaClO}_{4}$ & $\begin{array}{l}1.3 \pm 0.1 \\
1.85 \pm 0.1\end{array}$ & - & - & - & - \\
\hline 15 & spectr. & $5 \mathrm{M} \mathrm{NaClO}_{4}$ & 1.5 & 0.63 & 0.088 & 0.0032 & - \\
\hline 16 & $\begin{array}{l}\text { spectr. } \\
\text { calorim. }\end{array}$ & $4 \mathrm{M} \mathrm{LiClO}_{4}$ & $0.92 \pm 0.07$ & - & - & - & 13.6 \\
\hline 17 & spectr. & $3 \mathrm{M} \mathrm{NaClO}_{4}$ & $0.99 \pm 0.15$ & $0.40 \pm 0.06$ & - & - & - \\
\hline
\end{tabular}


of copper(II) chloride complexes in $5 \mathrm{M} \mathrm{Na}\left(\mathrm{ClO}_{4}\right.$, Cl) medium.

Several difficulties are encountered when weak complexes, such as those between copper(II) and chloride, are studied. The most serious of these is introduced by the need to substitute ligand $\left(\mathrm{Cl}^{-}\right)$ for a great part of medium - in this case perchlorate - in order to promote complex formation. Assignment of activity coefficients to facilitate interpretation of the data is complicated by this variation of the medium.

Another difficulty, when studying weak complexes with calorimetry, derives from the small heat effect obtained. However, the technique used in this investigation, flow microcalorimetry, is, from our experience, well suited for the measurement of small heat effects with good accuracy.

\section{EXPERIMENTAL}

Chemicals. The copper(II) perchlorate stock solution was prepared ${ }^{26}$ from $\mathrm{CuO}$ (Merck p.a.) and perchloric acid (Merck p.a.). The solution was analyzed for copper by electrodeposition ${ }^{27}$ and for $\mathrm{H}^{+}$potentiometrically.

Sodium perchlorate stock solution was prepared ${ }^{28}$ from $\mathrm{Na}_{2} \mathrm{CO}_{3}$ (Merck p.a.) and perchloric acid (Merck p.a.).

Sodium chloride (Merck p.a.) was recrystallized in water, the crystals were dried at $200^{\circ} \mathrm{C}$ and stored in a desiccator.

The compositions of the solutions used in the calorimetric measurements were

$\begin{array}{cc}\text { Solution } a & 5 \mathrm{M} \mathrm{NaClO}_{4} \\ & \simeq 0.015 \mathrm{M} \mathrm{HClO}_{4} \\ \text { Solution } b & A \mathrm{M} \mathrm{Cu}\left(\mathrm{ClO}_{4}\right)_{2} \\ & (5-2 A) \mathrm{M} \mathrm{NaClO}_{4} \\ \simeq & 0.015 \mathrm{M} \mathrm{HClO}_{4} \\ \text { Solution } c & B \mathrm{M} \mathrm{NaCl} \\ & (5-B) \mathrm{M} \mathrm{NaClO} \\ & \simeq 0.015 \mathrm{M} \mathrm{HClO}_{4}\end{array}$

The solutions were acidified to suppress the hydrolysis of copper(II).

Apparatus. For the measurements an LKB Flow microcalorimeter (10700-1) was used. The thermal output was amplified by a Keithley 150 B Microvolt amplifier and recorded on a potentiometric recorder.
The reactants were passed through the mixing cell by means of two peristaltic pumps (LKB Vario Perpex II). The pumps were calibrated frequently by weighing the amount of water pumped in a known amount of time. It was found that the flow rates changed less than $0.2 \%$ during an experiment, usually about five hours. The flow, $\phi\left(\mathrm{cm}^{3} \mathrm{~h}^{-1}\right)$, of the mixing reactants covered a range of values between 1.5 and $25 \mathrm{~cm}^{3} \mathrm{~h}^{-1}$.

The mixing cell used was a 24-carat gold channel, about $0.7 \mathrm{~cm}^{3}$ in volume. The detector sensitivity was $0.07 \mu \mathrm{V} / \mu \mathrm{W}$ and the calibration current had an accuracy of $\pm 0.1 \%$.

Calorimetric procedure. The calorimetric measurements were performed in the following way. The base line output potential was taken when solution $a$ (ionic medium) and solution $c$ (chloride solution) were pumped through the cell. When a stable base line was obtained, solution $a$ was replaced by solution $b$ (copper(II) solution). In this way the heat of dilution of chloride into the medium was automatically corrected for. The base line shift obtained then had to be corrected for the heat of dilution of the metal ion [copper(II)], which had to be determined in separate experiments.

For copper(II) concentrations less than about 0.40 $M$, it was found that

$$
\Delta H_{\text {dilution }}\left(J \mathrm{~mol}^{-1}\right)=-1030 \Delta\left[\mathrm{Cu}^{2+}\right]
$$

where $\Delta\left[\mathrm{Cu}^{2+}\right]$ is the difference between the final and initial copper(II) concentration when a $\mathrm{Cu}\left(\mathrm{ClO}_{4}\right)_{2}$ solution (medium $5 \mathrm{M} \mathrm{ClO}_{4}^{-}$) is diluted in $5 \mathrm{M} \mathrm{NaClO}_{4}$.

\section{RESULTS AND CALCULATIONS}

The calorimetric data obtained are collected in Table 2. The range of copper concentration covered is $0.004-0.35 \mathrm{M}$ and of chloride $0.03-3.5 \mathrm{M}$. The measured heat effect corrected for the heats of dilution is $Q_{\text {exp }}$.

The calorimetric data were treated with the least-squares computer program LETAGROP/ KALLE $^{30}$ and also with a new version of LETAGROP,${ }^{31}$ linked with SUBHTF ${ }^{32}$ (a subroutine form of HALTAFALL).

The results of the calculations are given in Table 3. The $\Delta \mathrm{H}$-values were obtained using the equilibrium constants given by Bjerrum and Skibsted. ${ }^{15} \mathrm{~A}$ poorer fit to the experimental data was obtained 
Table 2. Calorimetric data for the $\mathrm{Cu}^{2+}-\mathrm{Cl}^{-}$system in $5 \mathrm{M} \mathrm{Na}\left(\mathrm{ClO}_{4}, \mathrm{Cl}\right)$ at $25^{\circ} \mathrm{C}$. $Q_{\text {calc }}$ is the heat effect calculated with the $\beta$ and $\Delta H_{\beta}$ values in Table 3 .

\begin{tabular}{|c|c|c|c|c|c|}
\hline $\begin{array}{l}{\left[\mathrm{Cu}^{2+}\right]} \\
\mathbf{M}\end{array}$ & $\begin{array}{l}\phi_{\mathrm{Cu}} \\
\mathrm{ml} / \mathrm{h}\end{array}$ & $\begin{array}{l}{\left[\mathrm{Cl}^{-}\right]} \\
\mathbf{M}\end{array}$ & $\begin{array}{l}\phi_{\mathrm{Cl}} \\
\mathrm{ml} / \mathrm{h}\end{array}$ & $\begin{array}{l}Q_{\exp } \\
\mathbf{J} / \mathbf{h}\end{array}$ & $\underset{\mathrm{J} / \mathrm{h}}{Q_{\text {calc }}-Q_{\exp }}$ \\
\hline 0.394 & $\begin{array}{r}11.69 \\
22.76 \\
19.33 \\
11.57 \\
6.87 \\
14.42 \\
5.55 \\
5.03 \\
4.69 \\
4.75\end{array}$ & 0.300 & $\begin{array}{r}1.43 \\
4.42 \\
4.32 \\
4.30 \\
4.53 \\
10.53 \\
4.28 \\
4.37 \\
7.66 \\
4.53\end{array}$ & $\begin{array}{l}1.78 \\
5.25 \\
5.10 \\
4.66 \\
4.20 \\
9.39 \\
3.70 \\
3.70 \\
4.82 \\
3.69\end{array}$ & $\begin{array}{r}+0.02 \\
+0.06 \\
0.00 \\
-0.02 \\
-0.01 \\
+0.01 \\
+0.05 \\
-0.04 \\
-0.08 \\
-0.04\end{array}$ \\
\hline 0.0146 & $\begin{array}{l}5.26 \\
4.99 \\
5.29 \\
5.00\end{array}$ & 1.00 & $\begin{array}{l}4.96 \\
6.59 \\
8.35 \\
1.72\end{array}$ & $\begin{array}{l}0.188 \\
0.203 \\
0.229 \\
0.299\end{array}$ & $\begin{array}{r}-0.003 \\
0.000 \\
0.000 \\
-0.011\end{array}$ \\
\hline 0.0734 & 5.00 & & 1.72 & 1.35 & +0.03 \\
\hline 0.0146 & $\begin{array}{r}11.46 \\
4.58 \\
4.66 \\
11.46 \\
11.44 \\
4.58\end{array}$ & $\begin{array}{l}3.00 \\
5.00 \\
3.00\end{array}$ & $\begin{array}{r}4.66 \\
4.85 \\
11.46 \\
4.66 \\
4.63 \\
4.85\end{array}$ & $\begin{array}{l}0.724 \\
0.466 \\
0.57 \\
1.58 \\
2.04 \\
0.86\end{array}$ & $\begin{array}{c}+0.006 \\
-0.008 \\
+0.01 \\
+0.04 \\
+0.06 \\
0.00\end{array}$ \\
\hline 0.0365 & 11.85 & 5.00 & 6.40 & 5.86 & -0.02 \\
\hline 0.0146 & $\begin{array}{l}4.67 \\
4.58\end{array}$ & $\begin{array}{l}3.00 \\
5.00\end{array}$ & $\begin{array}{r}11.48 \\
4.85\end{array}$ & $\begin{array}{l}0.965 \\
1.01\end{array}$ & $\begin{array}{c}+0.021 \\
0.00\end{array}$ \\
\hline 0.0365 & 10.05 & & 18.46 & 5.80 & 0.00 \\
\hline 0.0146 & 4.66 & & 11.46 & 1.09 & 0.00 \\
\hline
\end{tabular}

when the equilibrium constants given by SchwingWeill ${ }^{12}$ were used.

From the present data it was not possible to determine $\Delta \mathbf{H}$ for the formation of $\mathrm{CuCl}_{4}^{2-}$. It is seen from Fig. 1 that $\mathrm{CuCl}_{4}^{2-}$ does not exist in noticeable amounts in the region studied by us.

In the calculations, it has been assumed that the activity coefficients are constant, although part of the experimental data have been obtained in a region where a large fraction of the medium ions has been replaced by chloride ions. The good fit of the data over the whole concentration range gives some support to this assumption.

Some $\Delta H_{1}$-values that have been reported in the literature are listed in Table 1. Several of these values ${ }^{16,21}$ are comparable to the $\Delta H_{1}$-value determined by us. This agreement may be coincidental however; in the earlier investigations ${ }^{16,21}$ it was assumed that only the monoligated complex was formed. Furthermore the ionic media used were not the same as used by us.

It is of interest to note as well that the present investigation of the $\mathrm{Cu}(\mathrm{II})-\mathrm{Cl}$ system seems to be the first in which the $\Delta H$ for the formation of $\mathrm{CuCl}_{2}$ and $\mathrm{CuCl}_{3}^{-}$as well as $\mathrm{CuCl}^{+}$has been determined.

In Table 4 the thermodynamic parameters $\Delta G^{\circ}$, $\Delta H^{\circ}$ and $\Delta S^{\circ}$ for the formation of $\mathrm{Cu}^{2+}-\mathrm{Cl}^{-}$ complexes are given.

In Table 5 the $\log K$ and $\Delta H^{\circ}$-values for some metal-chloride complexes are compared. The trend 
Table 3. Results from the calculations made with the LETAGROP program on data of Table 2. The given uncertainties are $3 \sigma$. The calculations gave $\sigma\left(Q_{\text {calc }}-Q_{\text {exp }}\right)=0.032 \mathrm{~J}$.

\begin{tabular}{ll}
\hline$\beta_{\mathrm{i}}$ & $\begin{array}{l}\Delta H_{\mathrm{i}} \\
\mathrm{kJ} \mathrm{mol}\end{array}$ \\
\hline$\beta_{1}=1.5^{a}$ & $\Delta H_{1}=12.30 \pm 0.1$ \\
$\beta_{2}=0.63^{a}$ & $\Delta H_{\beta 2}=23.0 \pm 1.5$ \\
$\beta_{3}=0.088^{a}$ & $\Delta H_{\beta 3}=11 \pm 4$ \\
\hline
\end{tabular}

${ }^{a}$ From Ref. 15.

in the stepwise $\log K$ and $\Delta H^{\circ}$ values for $\mathrm{Cu}(\mathrm{II})$ is similar to the trend observed in these parameters for $\mathrm{Zn}(\mathrm{II})$ and is to be expected for the interaction between a typical (a)-acceptor ("hard") and the

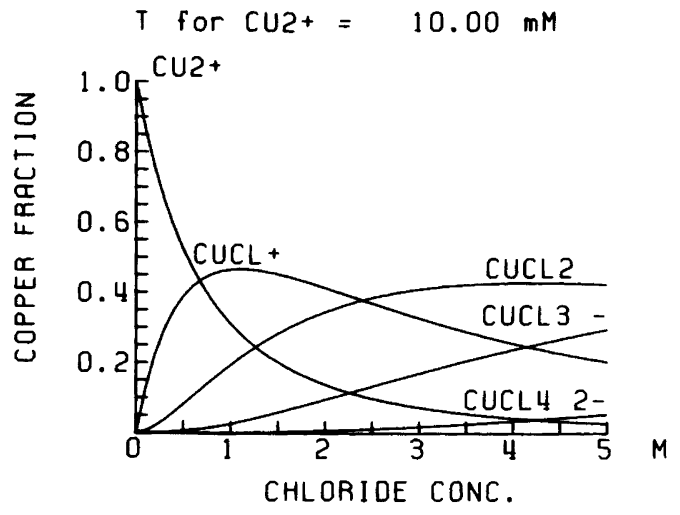

Fig. 1. Distribution of copper species as a function of chloride concentration in $5 \mathrm{M} \mathrm{Na}\left(\mathrm{ClO}_{4}, \mathrm{Cl}\right)$ at $25^{\circ} \mathrm{C}$. Plot produced by the SOLGASWATER ${ }^{29}$ program with the equilibrium constants from Ref. 15.

Table 4. Calculated values of $\Delta G^{\circ}, \Delta H^{\circ}$, and $\Delta S^{\circ}$ for the stepwise complex formation $\mathrm{Cu}^{2+}-\mathrm{Cl}^{-}$in $5 \mathrm{M}$ $\mathrm{Na}\left(\mathrm{ClO}_{4}, \mathrm{Cl}\right)$ at $25^{\circ} \mathrm{C}$.

\begin{tabular}{lllcc}
\hline Complex & $K$ & $\begin{array}{l}\Delta G^{\circ} \\
\mathrm{JJ} \mathrm{mol}^{-1}\end{array}$ & $\begin{array}{l}\Delta H^{\circ} \\
\mathrm{kJ} \mathrm{mol}^{-1}\end{array}$ & $\begin{array}{c}\Delta S^{\circ} \\
\mathrm{J} \mathrm{mol}^{-1} \mathrm{~K}^{-1}\end{array}$ \\
\hline $\mathrm{CuCl}^{+}$ & $1.5^{a}$ & -1.0 & 12.3 & 44.6 \\
$\mathrm{CuCl}_{2}$ & $0.42^{a}$ & +2.2 & 10.7 & 28.5 \\
$\mathrm{CuCl}_{3}^{-}$ & $0.14^{a}$ & +4.9 & -12.0 & -56.7 \\
\hline
\end{tabular}

${ }^{a}$ From Ref. 15.

Table 5. $\log K$ and $\Delta H$-values for the stepwise formation of chloride complexes of $\mathrm{Zn}(\mathrm{II}), \mathrm{Cd}(\mathrm{II}), \mathrm{Hg}(\mathrm{II})$ and $\mathrm{Cu}(\mathrm{II})$ at $25^{\circ} \mathrm{C}$.

\begin{tabular}{|c|c|c|c|c|c|}
\hline $\begin{array}{l}\text { Metal } \\
\text { ion }\end{array}$ & Complex & $\log K$ & $\begin{array}{l}\Delta H \\
\mathrm{~kJ} \mathrm{~mol}^{-1}\end{array}$ & Medium & Ref. \\
\hline $\mathrm{Zn}^{2+}$ & $\begin{array}{l}\mathrm{ZnCl}^{+} \\
\mathrm{ZnCl}_{2} \\
\mathrm{ZnCl}_{3}^{-}\end{array}$ & $\begin{array}{l}0.147 \\
0.418 \\
0.212\end{array}$ & $\begin{array}{l}17 \pm 2 \\
12 \pm 1.4 \\
-3.4 \pm 7\end{array}$ & $4 \mathrm{M} \mathrm{LiClO}_{4}$ & 33 \\
\hline $\mathrm{Cd}^{2+}$ & $\begin{array}{l}\mathrm{CdCl}^{+} \\
\mathrm{CdCl}_{2} \\
\mathrm{CdCl}_{3}^{-} \\
\mathrm{CdCl}^{+} \\
\mathrm{CdCl}_{2} \\
\mathrm{CdCl}_{3}^{-} \\
\mathrm{CdCl}_{4}^{2-}\end{array}$ & $\begin{array}{r}1.58 \\
0.64 \\
0.18 \\
1.77 \\
0.70 \\
0.64 \\
-0.55\end{array}$ & $\begin{array}{c}-0.42 \\
0.08 \\
7.74 \\
-2.8 \\
-2.7 \\
6.28 \\
24.7\end{array}$ & $\begin{array}{l}3 \mathrm{M} \mathrm{NaClO}_{4} \\
4 \mathrm{M} \mathrm{Li}\left(\mathrm{ClO}_{4}, \mathrm{Cl}\right)\end{array}$ & 34 \\
\hline $\mathrm{Hg}^{2+}$ & $\begin{array}{l}\mathrm{HgCl}^{+} \\
\mathrm{HgCl}_{2} \\
\mathrm{HgCl}_{3}^{-} \\
\mathrm{HgCl}_{4}^{2-}\end{array}$ & $\begin{array}{l}7.07 \\
6.91 \\
1.08 \\
1.09\end{array}$ & $\begin{array}{r}-24.2 \pm 1.0 \\
-27.2 \pm 1.5 \\
-4.3 \pm 0.9 \\
-6.2 \pm 1.0\end{array}$ & $3 \mathrm{M} \mathrm{NaClO}_{4}$ & 36 \\
\hline $\mathrm{Cu}^{2+}$ & $\begin{array}{l}\mathrm{CuCl}^{+} \\
\mathrm{CuCl}_{2} \\
\mathrm{CuCl}_{3}^{-}\end{array}$ & $\begin{array}{r}0.18 \\
-0.38 \\
-0.85\end{array}$ & $\begin{array}{r}12.3 \pm 0.1 \\
10.7 \pm 1.5 \\
-12 \pm 4\end{array}$ & $5 \mathrm{M} \mathrm{Na}\left(\mathrm{ClO}_{4}, \mathrm{Cl}\right)$ & This work \\
\hline
\end{tabular}


chloride ion. For comparison, data are also given in the Table for a representative (b)-acceptor, $\mathrm{Hg}$ (II) and for a "mild" (b)-acceptor, Cd(II).

It should also be added that the analysis of the $\mathrm{Cu}(\mathrm{II})-\mathrm{Cl}$ thermodynamic data summarized in Table 4 could possibly be further refined. One could attempt to take into account the proportion of inner and outer sphere complexes formed. ${ }^{37}$ However, attempts that have been made to estimate the formation constant for outer and inner sphere $\mathrm{CuCl}^{+}$ complexes ${ }^{20,21}$ are somewhat speculative. Therefore we have not considered it worthwhile to reinterpret our thermodynamic data for $\mathrm{Cu}^{2+}-\mathrm{Cl}^{-}$ by estimating the proportion of inner and outer sphere complexes which must necessarily be based on an uncertain estimate of their respective formation constants.

Acknowledgements This work has been supported by the Swedish Natural Science Research Council. Dr. J. Marinsky is thanked for the linguistic revision.

\section{REFERENCES}

1. Bjerrum, J. K. Dan. Vidensk. Selsk. Mat.-Fys. Medd. 22 (1946) No. 18.

2. McConnell, H. and Davidson, N. J. Am. Chem. Soc. 72 (1950) 3164.

3. Näsanen, R. Acta Chem. Scand. 4 (1950) 140.

4. Kruh, R. J. Am. Chem. Soc. 76 (1954) 4865.

5. Lister, M. W. and Rosenblum, P. Can. J. Chem. 38 (1960) 1827.

6. Mironov, V. E., Makashev, Yu. A., Mavrina, I. Ya. and Kryzhanovskii, M. M. Russ. J. Inorg. Chem. 15 (1970) 668 (Russian page 1301).

7. Libus, Z. Inorg. Chem. 12 (1973) 2972.

8. Schwing-Weill, M.-J. Bull. Soc. Chim. Fr. (1973) 823.

9. Khan, M. A. Thesis, Université L. Pasteur, Strasbourg 1975.

10. Blokhin, V. V., Razmyslova, L. I., Shalaevskaya, M. I., Makashev, Yu. A. and Mironov, V. E. Russ. J. Phys. Chem. 48 (1974) 275 (Russian page 469).

11. Ashurst, K. G. National Institute for Metallurgy, Report 1712, Randburg, South Africa 1975.

12. Khan, M. A. and Schwing-Weill, M.-J. Inorg. Chem. 15 (1976) 2202.

13. Carlsson, B. and Wettermark, G. J. Inorg. Nucl. Chem. 38 (1976) 1525.

14. Koneva, T. N. and Fedorov, V. A. Russ. J. Inorg. Chem. 21 (1976) 616 (Russian page 1132).

15. Bjerrum, J. and Skibsted, L. H. Acta Chem. Scand. A 31 (1977) 673.

Acta Chem. Scand. A 36 (1982) No. 1
16. Koneva, T. N., Fedorov, V. A. and Trofinov, G. L. Russ. J. Phys. Chem. 51 (1977) 470 (Russian page 793).

17. Sjöberg, S. Acta Chem. Scand. A 31 (1977) 729.

18. Kennedy, M. B. and Lister, M. W. Can. J. Chem. 44 (1966) 1709.

19. Almemark, M. and Arnek, R. Unpublished results.

20. Blokhin, V. V., Regulin, G. K., Anufrienko, V. F., Makashev, Yu. A. and Mironov, V. E. Russ. J. Phys. Chem. 44 (1970) 1512 (Russian page 2654).

21. Blokhin, V. V., Razmyslova, L. I., Makashev, Yu. A. and Mironov, V. E. Russ. J. Phys. Chem. 48 (1974) 82 (Russian page 151).

22. Morris, D. F. C. and Short, E. L. J. Chem. Soc. (1962) 2672.

23. Grimaldi, M. and Liberti, A. J. Chromatogr. 15 (1964) 510.

24. Hutchinson, M. H. and Higginson, W. C. E. J. Chem. Soc. Dalton Trans. 12 (1973) 1247.

25. Sato, T. and Kato, T. J. Inorg. Nucl. Chem. 39 (1977) 1205.

26. Berecki-Biedermann, C. Ark. Kemi 9 (1956) 175.

27. Vogel, A. I. Textbook of Quantitative Inorganic Analysis, 4th Ed., Longman, London 1978, p. 532.

28. Biedermann, G. Ark. Kemi 9 (1956) 277.

29. Eriksson, G. Anal. Chim. Acta 112 (1979) 375.

30. Arnek, R. Ark. Kemi 32 (1970) 81.

31. Sundstrand, S. MODFNK, the use of LETAGROP for ones own model functions. Draft. 1975.

32. Puigdomenech, I. and Wallin, T. SUBHTF, $a$ subtroutine form of the HALTAFALL program. TRITA-OOK-2012, 1980.

33. Fedorov, V. A., Chernikova, G. E. and Mironov, V. E. Zh. Neorg. Khim. 15 (1970) 2100.

34. Gerding, P. and Jönsson, I. Acta Chem. Scand. 22 (1968) 2247.

35. Fedorov, V. A., Kripin, L. I. and Mironov, V. E. Russ. J. Inorg. Chem. 17(1972) 641 (Russian page 1233).

36. Arnek, R. Ark. Kemi 24 (1965) 531.

37. Ahrland, S. Coord. Chem. Rev. 8 (1972) 21.

Received May 15, 1981. 